\title{
Influence of Application Readiness,Trust and E-Service Quality Against Purchase Interest in E-Commerce Xin Jabodetabek
}

\author{
Yendry Saputra ${ }^{1}$ \\ Mercu Buana University, Jakarta
}

\author{
Dipa Mulia $^{2}$ \\ Mercu Buana University, Jakarta
}

\begin{abstract}
The purpose of this research is to know and analyze how much influence the variable Application Readiness (Perceived Ease of Use and Perceived Usefulness), Trust and E-Service Quality to Purchase Interest in E-commerce $X$ in Jabodetabek. This study used a purposive sampling method with a Hair theory formula amounting to 160 respondents. The data analysis technique used is a Structural equation Modeling (SEM) equation technique using the AMOS version 22 application. The results showed that the Application Readiness, trust, and E-Service Quality significantly affect the Purchase Interest, E-Service Quality has the biggest and most significant contribution to online Purchase Interest.
\end{abstract}

Keywords:- Perceived Ease of Use, Perceived Usefulness, trust, Quality Electronic Services, Purchase Interest, ECommerce.

\section{INTRODUCTION}

The penetration of internet users in Indonesia rose significantly. If the year 2014 is in the range of 88.1 million people, the year 2018 increased to 171.29 million people (APJII and BPS, 2019). The number of Internet users in Indonesia has increased by $94 \%$ within 4 years. Based on the results of APJII survey year 2018, it is known that the contribution of Internet users per region of all Internet users in Indonesia mostly live in Java Island which is the highest contribution region of $55.7 \%$ of Internet users while on Sumatra island several 21.6\%, Bali Island 6.6\%, Sulawesi Island $5.2 \%$ and Papua Island $10.9 \%$ Internet users in Indonesia also increase the digital economy in One of the drivers of the digital economy in Indonesia is e-Commerce. English Research Institute, Merchant Machine, released the list of ten countries with the fastest-growing e-commerce in the world the highest e-commerce user concentration in Indonesia namely Jabodetabek area as much as $20.4 \%$, followed by East Java as much as $17.8 \%$ and Central Java $12.7 \%$, while other provinces are still under 10\%.E-commerce $\mathrm{X}$ is one of the marketplaces in Indonesia that apply modern selling concept such as buying and selling in a mall (Online shopping mall).E-commerce $\mathrm{X}$ gives users a container to purchase goods, exchange information, give reviews, and recommend good stuff so that visitors or users easily make a decision when shoppingonline.

Based on data from the e-commerce app review in Playstore which was accessed on October 19, 2019, from 100 The last review was only $21 \%$ reviewer that gave 5 stars. While the other $58 \%$ reviewer gives 1 and 2 stars.

Based on that data it can be indicated that the customer's Purchase Interest in $e$-commerce $\mathrm{X}$ is low. This is due to some problems that can be seen from the last 100 reviews (negative reviews) of users of $e$-Commerce $\mathrm{X}$ applications among them are (1) related applications, (2) lack of trust, (3) lack of quality of electronic services, (4) promotion is reduced and (5) expensive price.

\section{LITERATURE}

\section{A. Purchase interest}

One's desire to buy a particular product or service via $e$ commerceis called 1. Purchase interest (Chen et al, 2010, fygenson\&pavlou, 2006, Kian et al, 2017).

The Purchase Interest indicator according to Yeh (2015) is as follows:

\section{a) Valuable Purchase}

A person's desire to gather information to know the benefits of a particular product before purchasing with the intention that the purchase is made valuable to him.

\section{b) Most preference}

An overview of the behavior of someone who has a key preference for a particular product, so that the position of the product is difficult to be replaced unless the product preference is true - No.

\section{c) Willlingness to trial}

One's desire to try to use a particular product is a form of interest and interest in owning the product.

\section{d) Recommendation}

One's tendency to discuss and recommend the product to others to Purchase Interest. 


\section{B. Perceived Ease of Use}

Saputro (2013), Dewi\&Warnika (2016) argues that the perception of individuals relating to the ease of using a computer (perceived ease of use) is a level in which individuals believe that using certain systems will be free from mistakes and many attempts. The perception of ease of use implicates behavior, the higher one's perception of ease of use perception of a system, the higher also the utilization rate of information technology. Indicator perception Ease of use:

\section{a) Ease of Learn}

Clearly understand how to learn the transaction system through a retail web or mobile application.

\section{b) Controllable}

The facility and features provided on the website ormobile application function properly.

\section{c) Clear and understandable)}

Meaning the facility or features of the website and mobile applications by its benefits, the features are presented fully and do not pose any other perception.

\section{d) Flexibility}

Tranwitness can be done with no barriers and can be done anytime without limitation by place and time.

\section{e) Easy to become skillful)}

Meaning in subsequent use consumers can access the website or mobile application easily.

\section{f) Easy to use}

Meaning through $e$-commerce transaction process can be done easily and dynamically.

\section{Perceived Usefulness}

The perception of benefits on its original definition is defined as the extent to which one believes that using a particular system will improve user performance (Davis, 1989). The perception of benefits is related to the user's attitude towards the information system and its use. Venkatesh and Davis (2000:201) Divide the dimensions of the perception of the benefits into the following:

\section{a) Improves Job Performance}

System usage can improve individual performance. Davis (1989) Defines the perception of benefits (Perceived Usefulness) as "the degree to which a person believes that using a particular system would enhance his or her job performance" (A level where one believes that the use of a certain system will be able to improve the work performance of the person). By definition, it can be interpreted that the benefits of using information technology can improve the performance and performance achievements of people using it.

\section{b) Increases Productivity}

System usage can increase individual productivity levels. The perception of benefits is a level where one believes that the use of a certain system will be able to increase the productivity of the person's work.

\section{c) Enhances Effectiveness}

System usage can improve the effectiveness of individual performance. If users understand the process of using the system then it will provide benefits to reduce the cognitive burden for users and have the ability to work effectively.

\section{D) The System is Useful}

The use of the system is beneficial for individuals. Davis defines the perception of this perceived usefulness based on the definition of the word useful i.e. capable of being used advantageously or can be used for profitable purposes. The perception of benefits is a benefit that individuals believe can be gained when using IT.

\section{The Trust}

In this study, trust was analyzed and discussed specifically in the context of e-commerce shopping and other researchers ' belief concepts in the traditional purchase dimension. Believe as a belief that the other party will behave reliably in a relationship exchange (Kim et al., 2004).

The indicators of customer confidence according to Haekal and Widjajanta (2016:181) consist of:

\section{Ability}

Ability refers to the competence and characteristics of the seller/organization in influencing and authorizing specific Territories. In this case, how the seller can provide, serve, until securing transactions from the disruption of the other party.

\section{The benevolence}

Kindness is the willingness of the seller to provide mutually beneficial satisfaction between himself and the consumer.

\section{Integrity}

Integrity relates to how the seller's behavior or habits in running its business. The information provided to the consumer is true by the facts or not.

\section{Predictability}

Predictability is the consistency of behavior by sellers. The ability of sellers to provide assurance of goods sold, so that customers can anticipate and predict the performance of sellers.

\section{E. E-Service Quality}


Zeithmal, Parasuraman, and Malhotra (2002) in Zemblyte (2015) defines e-service qualityas the capability of efficiency ofwebsite facilities in providing the effectiveness of shopping activities, buying and selling and delivery of both products and services.

TatikSuryani (2013:254) in Nurrizal, 2015 mentioning indicators that can measure $e$-Service quality is website design, reliability, responsiveness, trust, and personalization. According to (Zemblyte, 2015) 14 dimensions of previous $e$ Service quality is divided into 3 scale measurements namely (1) a core e-service quality scale (e-S-qual), (2) e-Service quality recovery scale (e-RECs-qual) and (3) website Quality scale $(W-S$-qual $)$

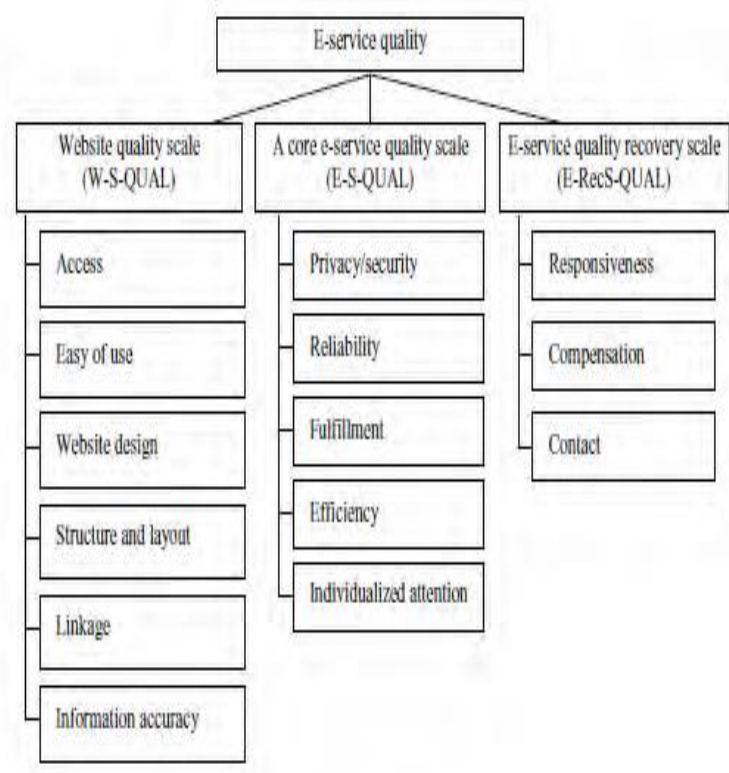

Fig 1: Conceptual scale E-Service Quality

Zemblyte proves that the third E-service quality of the scale generates 4 indicators from the consumer perspective:

\section{Compensation}

Compensation is related to the response and handling of the transaction process failure and fulfillment of repairs .

\section{Responsiveness and Fulfillment (responsiveness and fulfillment)}

Responsiveness and Fulfillment is the fulfillment of the Organization's commitment to receiving consumer complaints, providing clear information, and providing explanations and clarity to consumers.

\section{Website Operation (Web site operation)}

Website Operation is the convenience of websites and mobile applications.

\section{Reliability}

ISSN No:-2456-2165

Reliability is a depiction of the relationship between consumers and organizations such as imagery and reputation and the organization's ability to provide .

\section{CONCEPTUAL FRAMEWORK}

The thought framework is a chart describing systematically the research logic linking concepts used. According to an explanation then the skeleton of thought is as follows :

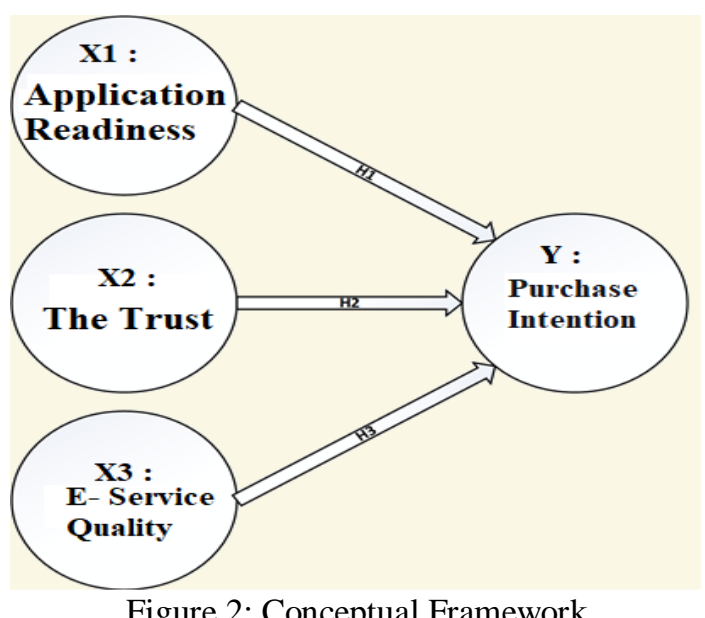

Figure 2: Conceptual Framework

\section{a) Hypothesis}

H1: Application Readiness in e-commerce $X$ has a significant influence on Purchase Interest.

H2: The trust in online shopping in X e-commerce has an impact on Purchase Interest.

H3: E-Service Quality in e-commerce X has a significant influence on Purchase Interest.

\section{POPULATION AND SAMPLES}

The population in This researchis a person who has made a purchase in e-commerce $\mathrm{X}$ in the JaBoDeTaBek area.As for the sampling used is purposive sampling with restrictions:

a) Respondents should have made a product purchase in the e-commerce " $\mathrm{X}$ " in the past year.

b) Respondents already have their income.

c) Respondents are at least 18 years old.

d) Domicile of respondents in JaBoDeTaBek area

e) The population is unknown, the minimum sample amount is 5 to 10 times the number of question items contained in the questionnaire.

The Total questions in this study were 16 questions, so the minimum sample size of this study was between $16 \times 5=$ 80 to $16 \times 10=160$. So the number of samples taken in this study was 80-160 respondents.

\section{DATA COLLECTION METHODS}


By using the survey method through a list of questions (questionnaire) that are distributed to respondents. Based on its type, data differentiated into two namely primary data and data.

1. Primary Data:data obtained from the questionnaire results circulated to the respondent, in this case, is a person who has purchased a product (not a service) in $\mathrm{X}$ e-commerce in one year

2. Secondary data: collected data is available. This data source is from the company as well as from the related literature, articles, and journals and is used in this research.

\section{a) Data Analysis Methods}

Data obtained by researchers analyzed using the software SEM AMOS (Analysis of Moment Structure).There are also tested instruments, the validity test of the reliability test, andthe outliers test.

\section{1) SEM Procedure}

This stage includes the following steps:

1. Defining the latent variables.

2. Defining the observed variables.

3. Defines the relationship between each latent variable and the observed variable that will form the measurement model.

4. Defines the causal relationship between variables observed to formA structural model.

\section{2) Identification}

There are three categories of identification result:

A. Under DomainKeys identified if the model with the number of estimated parameters is greater than the amount of known data.

B. Just DomainKeys identified if the model with the number of estimation parameters is equal to the amount of data known.

C. Over DomainKeys identified if the model with the number of estimation parameters is smaller than the amount of known data.

\section{RESULTS AND DISCUSSION}

Characteristic from 160 respondents who are the people of Jabodetabek, which is the respondent of more women, namely 110 people (69\%)with age 21 up to 30 years old, 30 respondents (18.75\%) Aged between 31-40 years, 6 respondents (3.75\%) Aged between 41-50 years, and 7 respondents $(4.38 \%)$ Less than 20 years old. Job respondents 16 respondents $(10.0 \%)$ Student, as many as 110 respondents $(68.75 \%)$ Was a private employee, as many as 18 respondents (11.25\%) From government employees/BUMN, as many as 9 respondents $(5.63 \%)$ From self-employed people, and 7 respondents $(4.38 \%)$ Not work/other.
1. That for the questionnaire statement in the Application Readiness variable (X1) consisting of 4 indicators ARE1ARE4 based on the spread of the data, as much as $1.56 \%$ of respondents answered strongly disagree, $11.09 \%$ expressed disagreement, as many as $36.41 \%$ of respondents declared neutral, as many as $46.09 \%$ said agreed, and as much as $4.84 \%$ of respondents expressed a very concur. The average result in this statement is 3.42 which means that in the Interperformance interval it enters into the "agree" category. The results showed that the Application Readiness in the scope of its samples was in a good category.

2. The questionnaire in the Trust variable (X2) consisting of 4 indicators OF TRU1-TRU4, based on the spread of its data as much as $1.25 \%$ of respondents answered strongly disagree, $11.09 \%$ expressed disagreement, as many as $37.03 \%$ of the respondents declared neutral, as many as $46.41 \%$ said agreed, and as much as $4.22 \%$ of respondents expressed a very concur.The average result in this statement is 3.41 which means that in the Interperformance interval it enters into the "agree" category. These results indicate that the belief in the scope of his sample in a good category.

3. Questionnaire in the variable E-Service Quality (X3) consisting of 4 indicators ESQ1-ESQ4, based on the spread of data as much as $2.81 \%$ of respondents answered with a very disagreement, $12.34 \%$ expressed disagreement, as many as $42.66 \%$ of respondents declared neutral, as many as $38.13 \%$ said agreed, and as much as $4.06 \%$ of respondents expressed a very concur.

The average result in this statement is 3.28 which means that in the Interperformance interval it enters into the "agree" category. The results showed that E-Service Quality in the scope of the samples was in a good category.

1. Questionnaire statement in the Purchase Interest variable (Y) consisting of 4 indicators PI1-

2. PI4, based on the spread of its data as much as $1.72 \%$ of respondents answered strongly disagree, $14.22 \%$ expressed disagreement, as many as $38.44 \%$ of the respondents declared neutral, as much as $40.94 \%$ of respondents expressed their consent, and as much as $4.69 \%$ of respondents expressed their consent

The average result in this statement is which means that in the Interperformance interval it enters into the "agree" category. These results show that Purchase Interest in the scope of a sample is in a good category.

\section{b) Test Model Measurement}

The validity test in this study using the Confirmatory Factor Analysis (CFA) test, CFA was used to test the validity and reliability of the model's immeasurable construction measurement. According to Hair et. al. in Wijanto (2008:66) stated that a construct has good reliability if:

\section{a) Descriptive analysis of Variable}


ISSN No:-2456-2165

1) The Construct Reliability (CR) value is $\geq 0.70$ and,

2) The value of Variance Extracted (its VE) $\geq 0.50$.

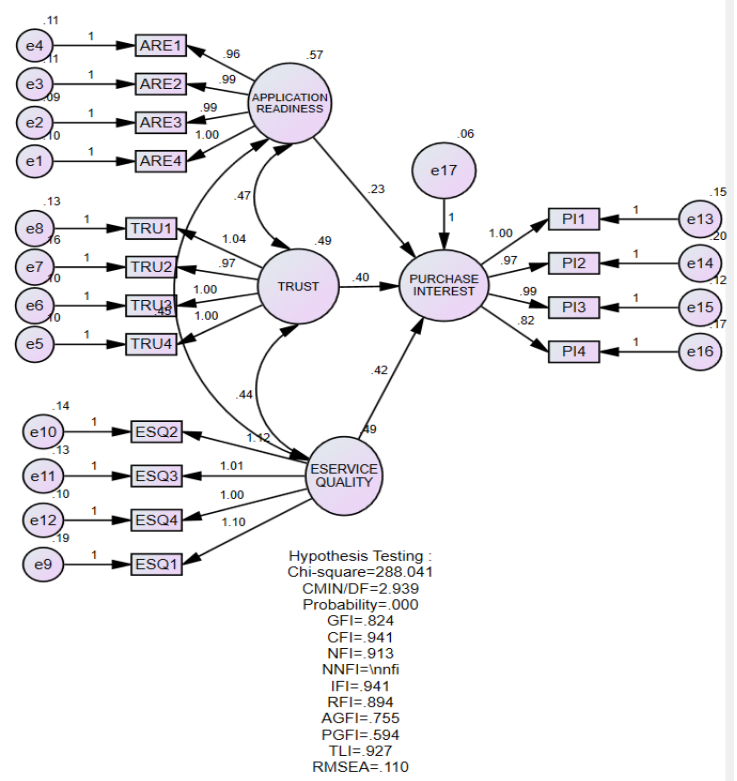

Figure 3: CFA Model Test Results

\begin{tabular}{|c|c|c|c|c|c|c|}
\hline \multicolumn{7}{|c|}{ Regression Weights: (Group number 1 - Default model) } \\
\hline & & & $\begin{array}{l}\text { Estim } \\
\text { ate }\end{array}$ & C.R. & $\mathrm{P}$ & $\begin{array}{l}\text { Descript } \\
\text { ion }\end{array}$ \\
\hline $\begin{array}{l}\text { ARE } \\
1 \\
\end{array}$ & $<-$ & $\begin{array}{l}\text { APPLICATION } \\
\text { READINESS }\end{array}$ & 1 & & & Valid \\
\hline $\begin{array}{l}\text { ARE } \\
2 \\
\end{array}$ & $<-$ & $\begin{array}{l}\text { APPLICATION } \\
\text { READINESS }\end{array}$ & 0,99 & $\begin{array}{l}20,81 \\
7\end{array}$ & $* * *$ & Valid \\
\hline $\begin{array}{l}\text { ARE } \\
2\end{array}$ & $<-$ & $\begin{array}{l}\text { APPLICATION } \\
\text { READINESS }\end{array}$ & 0,987 & $\begin{array}{l}20,01 \\
9\end{array}$ & $* * *$ & Valid \\
\hline $\begin{array}{l}\text { ARE } \\
4 \\
\end{array}$ & $<-$ & $\begin{array}{l}\text { APPLICATION } \\
\text { READINESS }\end{array}$ & 0,963 & $\begin{array}{l}19,78 \\
1 \\
\end{array}$ & $* * *$ & Valid \\
\hline $\begin{array}{l}\text { TRU } \\
4\end{array}$ & <-- & THE TRUST & 1 & & & Valid \\
\hline $\begin{array}{l}\text { TRU } \\
3 \\
\end{array}$ & $<-$ & THE TRUST & 0,999 & $\begin{array}{l}19,07 \\
6\end{array}$ & $* * *$ & Valid \\
\hline $\begin{array}{l}\text { TRU } \\
2 \\
\end{array}$ & $<-$ & THE TRUST & 0,971 & $\begin{array}{l}16,35 \\
8 \\
\end{array}$ & $* * *$ & Valid \\
\hline $\begin{array}{l}\text { TRU } \\
1 \\
\end{array}$ & $\begin{array}{l}<-- \\
-\end{array}$ & THE TRUST & 1,039 & $\begin{array}{l}18,24 \\
9\end{array}$ & $* * *$ & Valid \\
\hline $\begin{array}{l}\mathrm{ESQ} \\
4 \\
\end{array}$ & $\begin{array}{l}<- \\
-\end{array}$ & $\begin{array}{l}\text { ESERVICE_QUA } \\
\text { LITY }\end{array}$ & 1 & & & Valid \\
\hline $\begin{array}{l}\mathrm{ESQ} \\
3 \\
\end{array}$ & $\begin{array}{l}<- \\
-\end{array}$ & $\begin{array}{l}\text { ESERVICE_QUA } \\
\text { LITY }\end{array}$ & 1,01 & $\begin{array}{l}17,74 \\
1 \\
\end{array}$ & $* * *$ & Valid \\
\hline $\begin{array}{l}\mathrm{ESQ} \\
2 \\
\end{array}$ & $\begin{array}{l}<- \\
-\end{array}$ & $\begin{array}{l}\text { ESERVICE_QUA } \\
\text { LITY }\end{array}$ & 1,119 & 18,25 & $* * *$ & Valid \\
\hline $\begin{array}{l}\mathrm{ESQ} \\
1 \\
\end{array}$ & $\begin{array}{l}<- \\
-\end{array}$ & $\begin{array}{l}\text { ESERVICE_QUA } \\
\text { LITY }\end{array}$ & 1 & & & Valid \\
\hline PI1 & $\begin{array}{l}<-- \\
-\end{array}$ & $\begin{array}{l}\text { PURCHASE } \\
\text { INTEREST }\end{array}$ & 0,973 & $\begin{array}{l}15,50 \\
9\end{array}$ & $* * *$ & Valid \\
\hline $\mathrm{PI} 2$ & <-- & PURCHASE & 0,99 & 17,60 & $* * *$ & Valid \\
\hline
\end{tabular}

\begin{tabular}{|c|c|c|c|c|c|c|}
\hline & - & INTEREST & & 5 & & \\
\hline PI3 & $<-$ & $\begin{array}{l}\text { PURCHASE } \\
\text { INTEREST }\end{array}$ & 0,82 & $\begin{array}{l}14,69 \\
5\end{array}$ & $* * *$ & Valid \\
\hline PI4 & $<-$ & $\begin{array}{l}\text { PURCHASE } \\
\text { INTEREST }\end{array}$ & 1,103 & $\begin{array}{l}16,82 \\
2\end{array}$ & $* * *$ & Valid \\
\hline
\end{tabular}

Table 4:- Construc Validity test Results

The construction validity test states that of all indicators contained in the exogenous variable i.e. the ARE1-ARE4 indicator in the Application Readiness variable, the TRU1TRU4 indicator in the trust variable, the ESQ1-ESQ4 indicator in the E-Service Quality variable, and the PI1-PI4 indicator

In the Purchase, the Interest variable has a $C R$ value greater than 2.0 with a value of $\mathrm{p}$ smaller than 0.005 .

An indicator can also be said to be valid if its Loading Factor is greater than 0.5 Results of the Loading value Factor exogenous construction .

\begin{tabular}{|c|c|c|c|}
\hline \multicolumn{4}{|c|}{$\begin{array}{l}\text { Standardized Regression Weights: (Group number } 1 \text { - } \\
\text { Default model) }\end{array}$} \\
\hline & & & Estimate \\
\hline ARE1 & $<---$ & $\begin{array}{l}\text { APPLICATION } \\
\text { READINESS }\end{array}$ & 0,912 \\
\hline ARE2 & $<---$ & $\begin{array}{l}\text { APPLICATION } \\
\text { READINESS }\end{array}$ & 0,915 \\
\hline ARE3 & $<--$ & $\begin{array}{l}\text { APPLICATION } \\
\text { READINESS } \\
\end{array}$ & 0,927 \\
\hline ARE4 & $<---$ & $\begin{array}{l}\text { APPLICATION } \\
\text { READINESS }\end{array}$ & 0,921 \\
\hline TRU1 & $<---$ & THE TRUST & 0,897 \\
\hline TRU2 & $<---$ & THE TRUST & 0,859 \\
\hline TRU3 & $<--$ & THE TRUST & 0,911 \\
\hline TRU4 & $<---$ & THE TRUST & 0,912 \\
\hline ESQ1 & $<---$ & ESERVICE_QUALITY & 0,872 \\
\hline ESQ2 & $<---$ & ESERVICE_QUALITY & 0,900 \\
\hline ESQ3 & $<---$ & ESERVICE_QUALITY & 0,891 \\
\hline ESQ4 & $<---$ & ESERVICE_QUALITY & 0,910 \\
\hline PI1 & $<---$ & $\begin{array}{l}\text { PURCHASE } \\
\text { INTEREST }\end{array}$ & 0,892 \\
\hline PI2 & $<---$ & $\begin{array}{l}\text { PURCHASE } \\
\text { INTEREST }\end{array}$ & 0,857 \\
\hline PI3 & $<---$ & $\begin{array}{l}\text { PURCHASE } \\
\text { INTEREST }\end{array}$ & 0,906 \\
\hline PI4 & $<---$ & $\begin{array}{l}\text { PURCHASE } \\
\text { INTEREST }\end{array}$ & 0,835 \\
\hline
\end{tabular}


Table 5: The result of the Loading Factor of exogenous construction

Thus all indicators within an exogenous variable have fulfilled the assumption of validity.

\begin{tabular}{|c|c|c|c|c|c|c|c|}
\hline \multicolumn{2}{|c|}{ Measurement Model } & \multirow[b]{2}{*}{$\begin{array}{l}\text { Standard } \\
\text { Loading }\end{array}$} & \multirow[b]{2}{*}{$\begin{array}{l}\text { Standard } \\
\text { Loading }^{2}\end{array}$} & \multirow[b]{2}{*}{$\begin{array}{c}\text { Measurement } \\
\text { Errors (1-Std } \\
\text { Loading') }^{2}\end{array}$} & \multirow[b]{2}{*}{ Remarks } & \multicolumn{2}{|c|}{ Reliability } \\
\hline $\begin{array}{c}\text { Variabel } \\
\text { Laten }\end{array}$ & $\begin{array}{c}\text { Kode } \\
\text { Indikator }\end{array}$ & & & & & $\begin{array}{l}C R \geq \\
0,70\end{array}$ & $\begin{array}{l}V E \geq \\
0,50\end{array}$ \\
\hline \multirow{4}{*}{$\begin{array}{l}\text { Application } \\
\text { Readiness } \\
\text { (X1) }\end{array}$} & AREI & 0,912 & 0,832 & 0,168 & Reliabel & \multirow{4}{*}{0,956} & \multirow{4}{*}{0,844} \\
\hline & ARE2 & 0,915 & 0,837 & 0,163 & Reliabel & & \\
\hline & ARE3 & 0,927 & 0,859 & 0,141 & Reliabel & & \\
\hline & ARE4 & 0,921 & 0,848 & 0,152 & Reliabel & & \\
\hline \multirow{4}{*}{ Trust (X2) } & TRU1 & 0,897 & 0,805 & 0,195 & Reliabel & \multirow{4}{*}{0,942} & \multirow{4}{*}{0,801} \\
\hline & TRU2 & 0,859 & 0,738 & 0,262 & Reliabel & & \\
\hline & TRU3 & 0,911 & 0,830 & 0,170 & Reliabel & & \\
\hline & TRU4 & 0,912 & 0,832 & 0,168 & Reliabel & & \\
\hline \multirow{4}{*}{$\begin{array}{c}\text { E Service } \\
\text { Quality } \\
\text { (X3) }\end{array}$} & ESQ1 & 0,872 & 0,760 & 0,240 & Reliabel & \multirow{4}{*}{0,941} & \multirow{4}{*}{0,798} \\
\hline & ESQ2 & 0,900 & 0,810 & 0,190 & Reliabel & & \\
\hline & ESQ3 & 0,891 & 0,794 & 0,206 & Reliabel & & \\
\hline & ESQ4 & 0,910 & 0,828 & 0,172 & Reliabel & & \\
\hline \multirow{4}{*}{$\begin{array}{l}\text { Purchase } \\
\text { Interest (Y) }\end{array}$} & PII & 0,892 & 0,796 & 0,204 & Reliabel & \multirow{4}{*}{0,928} & \multirow{4}{*}{0,762} \\
\hline & PI2 & 0,857 & 0,734 & 0,266 & Reliabel & & \\
\hline & PI3 & 0,906 & 0,821 & 0,179 & Reliabel & & \\
\hline & PI4 & 0,835 & 0,697 & 0,303 & Reliabel & & \\
\hline
\end{tabular}

Table 6: Results of exogenous variable reliability test

The16 variable indicators are observed in an exogenous latent variable that has passed the validity test.

All value LoadingFactors $\geq 0.50$. While the results of the variableapplication readiness $\left(\bar{X}_{1}\right)$ Reliability test resulted in a good reliability in which the results of the Construct reliabity value $(\mathrm{CR})=0,956>0.7$, and the value of variance Extracted (VE) of $0,844>0.50$. A variable trust $\left(\mathrm{X}_{2}\right)$ reliability test results in agood reliability in which the results of the Construct reliabity value $(\mathrm{CR})=0,942>0.7$, and the value of variance Extracted (VE) of 0,801>0.50. E Service Quality $\left(\mathrm{X}_{3}\right)$ variable reliability test results result ingood reliability values where the result of the Construct reliabity value $(\mathrm{CR})=$ $0,941>0.7$, and the variance value Extracted (VE) of 0,798> 0.50 . The result of the Purchase Interest variable Reliability Test (Y) generates a good reliability value where the result of the Constructreliabity value $(\mathrm{CR})=0,928>0.7$, and the value of variance Extracted (VE) of 0,762> 0.50. Thus the exogenous latent variables have qualified test validity and reliability.

\section{c) Outliers Data (extreme numbers)}

Extreme numbers (outliers) is an observation that arises with values of both univariate and multivariate the expression that arise because of the combination of unique characteristics that it has and looks very much different from other observations. Outlier Data can be seen from the value of Mahalanobis distance that has $\mathrm{P} 1$ and $\mathrm{P} 2$. A record includes outliers if the value of P1 and P2 (both) generated is worth < 0.001. From the resulting data OUTPUT, AMOS generates that no data has a value of P1 and p2 $<0.001$ d) Fit Model

By looking at the output results from the initial Goodness of Fit Test, which there are still many unfit GOF Indexes, it can be concluded that the structural model in this study can be declared unfit (not fit). Therefore it is necessary to modify indices to produce a fit output model, resulting in the following output :

\begin{tabular}{|c|c|c|c|}
\hline GOF Index & $\begin{array}{c}\text { Cut-Off } \\
\text { Value }\end{array}$ & Output & Keterangan \\
\hline $\begin{array}{l}\text { Chi- } \\
\text { Square }\end{array}$ & $\begin{array}{l}\text { Chi-Square } \\
<\text { Chi- } \\
\text { Square } \\
\text { Tabel }= \\
122.28\end{array}$ & 122,371 & $\begin{array}{c}\text { Marginal } \\
\text { Fit }\end{array}$ \\
\hline Probability & $\mathrm{p}>0,05$ & 0,016 & $\begin{array}{c}\text { Marginal } \\
\text { Fit }\end{array}$ \\
\hline RMSEA & $\begin{array}{l}\text { RMSEA } \leq \\
0,08\end{array}$ & 0,047 & Fit \\
\hline GFI & GFI $\geq 0,9$ & 0,919 & Fit \\
\hline AGFI & $\mathrm{AGFI} \geq 0,9$ & 0,878 & $\begin{array}{c}\text { Marginal } \\
\text { Fit } \\
\end{array}$ \\
\hline CMIN/DF & $\begin{array}{l}\mathrm{CMIN} / \mathrm{DF} \leq \\
2\end{array}$ & 1,345 & Fit \\
\hline TLI & $\mathrm{TL} \underline{\mathrm{I}} \geq 0,95$ & 0,987 & Fit \\
\hline CFI & CFI $\geq 0.95$ & 0,990 & Fit \\
\hline NFI & NFI $\geq 0,90$ & 0,963 & Fit \\
\hline IFI & IFI $\geq 0.90$ & 0,990 & Fit \\
\hline RFI & RFI $\geq 0.90$ & 0,952 & Fit \\
\hline
\end{tabular}

Table 1.4 Goodness Of Fit Model Testing Results

\section{HYPOTHESES TEST RESULTS}

Analysis of structural model relationships (hypothesis testing)

The relationship between the construction in the hypothesis is demonstrated by the value of regression weights (Ghazali, 2014). To analyze more clearly about the influence of Application Readiness (X1), trust (X2), and E-Service Quality towards Purchase Interest

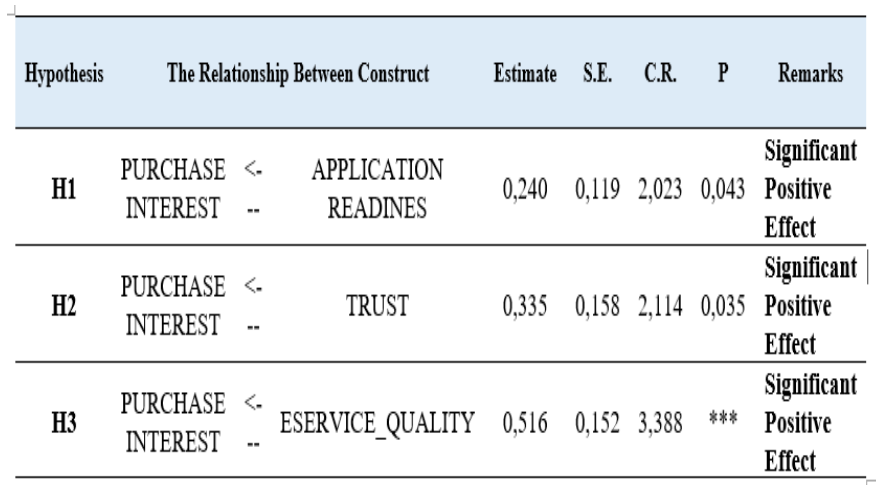

Table 7: hypotheses Test results 
1. There is a positive and significant influence of Application Readiness (X1) on Purchase Interest (Y)

According to table 4.12, the value of P-Values $=0.043$ $<\alpha=0.05$. The estimated value is a positive of the 0.240 meaning the Application Readiness variable (X1) positively affects the Buy interest variable (Y) of $24.0 \%$. Thus the H1 hypothesis in this study stated that "Application Readiness (X1) has a positive and significant effect on the Purchase Interest $(\mathrm{Y})$ " received.

2. There is a positive and significant influence of trust (X2) on Purchase Interest (Y)

According to table 4.12, the value of P-Values $=0.035<$ $\alpha=0.05$. The estimated value is positive which is 0.335 meaning that the trust variable (X2) is positively influential in the buying interest $(\mathrm{Y})$ variable by $33.5 \%$. Thus the $\mathrm{H} 2$ hypothesis in this study states that "belief (X2) has a positive and significant effect on the Purchase Interest (Y)" received.

3. There is a positive and significant influence on E-Service Quality (X3) on Purchase Interest (Y)

According to table 4.12, the value of P-Values $=0.000<$ $\alpha=0.05$. The estimated value is a positive that is 0.516 meaning that the E-Service Quality (X3) variable has a positive effect on the Buy interest variable (Y) of $51.6 \%$. Thus the H3 hypothesis in this study states that "E-Service Quality (X3) has a positive and significant effect on the Purchase Interest $(\mathrm{Y})$ " received.

\section{a) Test coefficient of determination/R Square $\left(R^{2}\right)$}

The structural evaluation of the model is done by looking at the coefficient of determination. The coefficient of determination aims to measure how far the ability of the model in explaining the variable variances of a dependent. The value of the coefficient of determination is between 0 and 1 . The value of the coefficient of determination $\left(\mathrm{R}^{2}\right)$ approaches the value 1 . The $R^{2}$ value explains how large the independent variables hypothesized in the equation can describe the dependent variables. Sugiyono (2016) explains the criteria for these $\mathrm{R}^{2}$ values in three classifications i.e. the values of $\mathrm{R}^{2}=$ $0.67,0.33$, and 0.19 as substantial, moderate, and weak. A structural relationship based on the value of Estimate, it can be explained that the Buy interest variable $(\mathrm{Y})$ is 0.953 , it indicates that a $95.3 \%$ interest buy $(\mathrm{Y})$ variable can be affected by an Application Readiness (X1) variable, trust (X2), and EService Quality (X3), while the remaining $4.7 \%$ is affected by other variables outside of the investigation.

\section{DISCUSSION}

In this section, the author displays the discussion of the results of the analysis, which is the effect of independent variables on the dependent variables that have been analyzed. It can be noted that all independent variables have a significant effect on the dependent variables. The explanation is as follows:

\section{Analysis of the influence of Application Readiness of Purchase Interest}

It can be seen that the resulting P-Values value is below the recommended $\mathrm{P}$-values value, where the $\mathrm{P}$-values of Application Readiness is $0.043<\alpha=0.05$. The estimated value is a positive of 0240 . It can be concluded that the Application Readiness variable has a positive and significant effect on the buy interest variables of $24.0 \%$.

The results of this research show that Application Readiness will influence customer's Purchase Interest. The findings of this research in line with the research of $\mathrm{Ha}$ and Nguyen (2019) stating that the Perceived Ease of Use and Usefulness has a positive effect on the consumer's Online Shopping Intention. E-commerce $\mathrm{X}$ if it can provide applications or good technology reception to consumers will increase the interest of consumer's purchase by $24 \%$ more positive, this shows the better application readiness of $\mathrm{X}$ ecommerce, the better the interest in buying consumers to products in e-commerce $\mathrm{X}$.

\section{Analyze the impact of trust in Purchase Interests}

It can be seen that the 2 hypotheses are received because the resulting $\mathrm{P}$-values value is below the recommended $\mathrm{P}$ values, of which $\mathrm{P}$-values trust is $0.035<\alpha=0.05$. The estimated value is a positive of 0.335 . So it can be concluded that the trust variable has a positive and significant effect on the buy interest variable by $33.5 \%$.

This suggests that consumers will increase their interest if their trust in E-commerce $\mathrm{X}$ is good. The better the trust caused by products and e-commerce applications will increase the interest of consumers ' buying as much as $33.5 \%$ in a positive way. E-commerce $\mathrm{X}$ will be the flagship e-commerce if it can make consumer confidence of products and applications arise. The result of this research was in line with Claudia Cindy Karnadjaja's research, Diyah Tulipa, RobertusSigitHaribowoLukito (2017) who stated that trust has a positive impact on the Online shopping interests, and the research of TutikSetyawati, Y. Djoko Suseno, Rahayutriastite (2016) which states that the belief has a

\section{Analysis of E-Service Quality influence on Purchase Interest}

It can be seen that the 2 hypotheses are received because the resulting $\mathrm{P}$-values value is below the recommended Pvalues value, where the P-values E-Service Quality is $0.000<$ $\alpha=0.05$. The estimated value is a positive of 0.516 . It can be concluded that the E-Service Quality variable has a positive and significant effect on the buy interest variable of $51.6 \%$.

This shows that good E-Service Quality in e-commerce $\mathrm{X}$ will have an impact on the interest in buying products in ecommerce X. The higher E-Service Quality in e-commerce X will increase the buying interest by $51.6 \%$. 
Unlike the research of Haslinda Hasan, Amran Harun, and MohdShaffran Zainal Rashid (2015) where the results showed that the Perceived Ease of Use had the biggest contribution in influencing Online Purchase Intention Consumers Online, in the results of this research shows that the variable E-Service Quality that has the largest and most significant contribution to the interest of buy or Online purchase Intention.

The results of this research are also different from the research of Ahmadian, Hagtalab, and Danaee (2017) which reveals that the quality of service, customer satisfaction, and overall quality of electronic services do not have a significant impact on consumer Purchase Interest.

The results of these research findings are in line with the research of Harti (2017) which reveals that E-Service Quality positively affects the Purchase Interest of online sites and research on Barriyah and Suyanto (2019) which reveals that the dimensions of E-Service Quality have a positive and significant influence on the purchase interest simultaneously. This proves that the more positive E-Service Quality in ecommerce it will be the higher the Purchase Interest is either seen from positive perception of e-commerce, product, and reference provided regarding a product.

\section{$>$ Managerial implications}

The results of this research are expected to provide managerial implications for e-commerce $X$ to increase the interest of buying through variable application readiness, trust, and E-Service Quality. Some practical implications can be described as follows:

1. Application Readiness significantly positively affects the interest of buying in e-commerce $\mathrm{X}$. This suggests that the company should improve the positive Application Readiness on e-commerce and increase the intensity of improvement in the section of ease and effectiveness of application technology. From the description of the query result data questionnaire variable applicationreadiness, it can be seen that the respondents who answered the most disagree are in the ARE1 indicator and ARE2 means that the indicator is the worst of its performance. The ARE1 indicator is the system is useful, i.e. $\mathrm{X}$ e-Commerce application should provide many benefits for the user to shop online so that consumers feel benefitting, its practical implications are that more contextual to e-commerce $\mathrm{X}$ is an existing feature related to configuring payments via Bank transfer in X e-commerce applications where it takes longer (about 1 business day), so it should be improved this payment configuration for a shorter time is less than 1 business day or a few minutes so that the user Feel beneficial and profitable from the effectiveness of time. Then the ARE2 indicator is effectiveness, is X e-commerce application must be practical and effective so that users do not feel the time wasted in shopping online is by way of upgrading the features in the application to be easier to use, for example on the existing shopping cart function but no feature deletes items in bulk or "Delete all items", consequently the user must keep one by one remove items if you want to delete in, this is considered less effective so it has to be upgraded or added to the feature so that the user feels its operation is practical and effective. Another example that needs to be improved on the effectiveness indicator is the notification feature or notification that already exists in an $\mathrm{X}$ e-commerce application, but currently only sent at the beginning of purchase and delivery of finished goods, there is no further notice of the progress of order status of goods that have been ordered, consequently, the user should see the status of goods manually in the application or e-commerce website $\mathrm{X}$ to So this needs to be improved namely the addition of advanced notifications such as ready-to-send items and courier notifications on the way to which buyers will feel that this feature is effective.

2. The trust has a significant positive impact on the Purchase Interest in e-commerce $\mathrm{X}$. Companies must increase their trust to give a positive impression on e-commerce to increase interest in buying. From the data description of the question results questionnaire the trust variable, it can be seen that the respondents who answered the most disagree are in the TRU2 indicator, and TRU1 means that the indicator is the worst of its performance. Indicator TRU2 is benevolence or kindness, ie e-commerce should always show the willingness to provide mutually beneficial satisfaction between the company and consumers so that consumers feel unharmed from online buying activities, for example by making better improvements in the warranty claim process to be easier so that the user will feel unharmed if there is damage to the product. Then indicator Ability or ability, that is, how e-commerce $\mathrm{X}$ can provide, serve, until secure transactions from the interference of other parties so that consumers become truly trusting with $\mathrm{X}$ e-commerce, for example by ensuring the delivery process of consumer orders according to the promised schedule and time and no disruption in the process, namely by evaluating the supplier, warehouse and courier to be able to coordinate as.

3. E-Service Quality significantly positively affects the interest of buying in e-commerce X. From a description of the query result data questionnaire variable E-Service Quality, it can be seen that the respondents who answered the most disagree are in the ESQ2 and ESQ1 indicators, meaning that the indicator is the worst performance. The ESQ2 indicator is Responsiveness and Fulfillfeness, which is Customer Service e-commerce $\mathrm{X}$ must provide a fast response to the email and phone is to make improvements such as giving deep training to the Customer Service to better answer questions and solve consumers. Then the ESQ1 indicator is Compensation, i.e e-commerce X should be more responsive to compensate if the product is not by 
the proof of booking confirmation which is for example by improving to return the goods by always picking up the goods in return by the consumer and replacing them faster.

\section{CONCLUSIONS AND SUGGESTIONS}

\section{a) Conclusion}

Based on the results of the research and discussion in previous chapters can be expressed several conclusions as follows:

1. Application readiness has a positive and significant effect on Purchase Interest. Meaning the better the Application Readiness then the Purchase Interest will go up.

2. The trust variable has a positive and significant effect on buyer interest. That means the better the trust then the buying interest will go up.

3. The E-Service Quality variable positively and significantly affect the buying interest. This means that the better EService Quality then the Purchase Interest will go up. The E-Service Quality variable is the most influential variable to buy interest.

b) Suggestions

Based on the results of the analysis of the discussion and some of the conclusions above, the suggestions that can be given to complement the results of this research, namely as follows:

\section{For the company}

The results of SEM analysis, indicating that the Application Readiness, trust, and E-Service Quality significantly affect the Purchase Interest, so the agency needs to do the following things:

a. As an effort to improve the Application Readiness, the company must increase the intensity of improvements in two indicators, namely the system is useful and effectiveness, because from the description of the data query results questionnaire variable applicationreadiness, it is known that the respondent who answered the most disagree is in the two indicators that mean the indicator is the worst performance. The system is useful, i.e. X eCommerce application should provide many benefits for the user to shop online so that consumers feel benefitting, its practical implications are that more contextual to ecommerce $\mathrm{X}$ is an existing feature related to configuring payments via Bank transfer in $\mathrm{X}$ e-commerce applications where it takes longer (about 1 business day), so it should be improved this payment configuration for a shorter time is less than 1 business day or a few minutes so that the user Feel beneficial and profitable from the effectiveness of time. Then the effectiveness, is $\mathrm{X}$ e-commerce application must be practical and effective so that users do not feel the time wasted in shopping online is by way of upgrading the features in the application to be easier to use, for example on the existing shopping cart function but no feature delete items in bulk or "Delete all items", consequently the user must keep one by one remove items if you want to delete in, this is considered less effective so it has to be upgraded or added to the feature so that the user feels its operation is practical and effective. Another example that needs to be improved on the effectiveness indicator is the notification feature or notification that already exists in an $\mathrm{X}$ ecommerce application, but currently only sent at the beginning of purchase and delivery of finished goods, there is no further notice of the progress of order status of goods that have been ordered, consequently, the user should see the status of goods manually in the application or ecommerce website $\mathrm{X}$ to So this needs to be improved namely the addition of advanced notifications such as ready-to-send items and courier notifications on the way to which buyers will feel that this feature is effective.

b. To increase the trust that will later affect the interest of buying in e-commerce, the company should pay attention to two indicators namely benevolence and Ability, because from the description of the data query results questionnaire variable Trust, it is known that the respondent who answered the most disagree is in the two indicators that mean the indicator is the worst performance. Benevolence indicator is e-commerce $\mathrm{X}$ should always show the willingness to provide mutually beneficial satisfaction between the company and consumers so that consumers feel unharmed from online buying activities, for example by making better improvements to the warranty claim process to be easier so that the user will feel unharmed if there is damage to the product. Ability indicator or ability, that is, how e-commerce $\mathrm{X}$ can provide, serve, until secure transactions from the interference of other parties so that consumers become truly trusting with $\mathrm{X}$ e-commerce, for example by ensuring the delivery process of consumer orders according to the promised schedule and time and no disruption in the process, namely by evaluating suppliers, warehouses and courier to be able to coordinate as.

c. To improve E-Service Quality which will be most impactful in e-commerce Purchase Interest, there must be an improvement in two important indicators namely Responsiveness and Fulfillfeness and Compensation because, from the data description of the question questionnaire the E-Service Quality variable, it is known that the respondent who answered most disagree is in the two indicators that mean the indicator is the worst performance. The Responsiveness and Fulfillfeness indicator are a Customer Service e-commerce X that must give a fast response to the email and phone are to make improvements such as training in-depth to Customer Service to better answer questions and solve consumers. The Compensation indicator is e-commerce $\mathrm{X}$ should be more responsive to compensate if the product is not by the proof of booking confirmation which is for example by making improvements to return the goods by always picking up the goods in return by the consumer and replacing them faster. 


\section{For further researchers}

A. Develop research on other types of e-commerce applications, such as travel online or specific to a product that is currently much needed medical e-commerce and have a large market share opportunities.

B. Expand the area of the respondents studied, which was previously limited to the Jabodetabek area. Later it can also cover a wider area.

C. Discussing other $\mathrm{Y}$ variable variables that may also be influenced by the Application Readiness, trust, and EService Quality variables such as purchasing sensitivity, customer satisfaction, and customer loyalty.

\section{REFERENCES}

[1]. Ahmadian, S., Hagtalab, H., Danaee H. (2017). The relationship between service quality, customer's esatisfaction, and overall quality of electronic services with airline tickets online purchase intention. International Journal of Advanced Studies in Humanities and Social Science, 6 (3), 221-226.

[2]. Barriyah, K., Suyanto, A. M. A. (2019). Pengaruh eservice quality terhadap minat beli pengunjung toko online shopee.co.id. e-Proceeding of Management, 6 (1), 321-329.

[3]. Chen, H. C., Hsu, I. C., \& Lin, C. C. (2010). The website attributes that increase consumer purchase intention: a conjoint analysis. Journal of Business Research, 63 (9), 1007-1014.

[4]. Chen \& Yu-Shan. (2010). The organizational identity: source and consequence. Management Decision, 49 (3), 384-404.

[5]. Davis F. D (1989). Perceived usefulness, perceived ease of use of information technology. Management Information System Quarterly,21-37.

[6]. Dewi, N. M. A. P., \& Warnika, I. G. K. (2016), Peran persepsi kemudahan penggunaan, persepsi manfaat dan persepsi resiko terhadap niat menggunakan mobile commerce di kota Denpasar. E-jurnal Manajemen Unud, 5 (4), 2606-2636.

[7]. Ha, N. T., Nguyen, T. L. H., Nguyen, T. L. P., Nguyen, T. D. (2019). The effects of trust on consumers' online purchase intention: an integration of TAM and TPB. Management Science Letter, 9, 1451-1460.

[8]. Haekal, A., Widjajanta, B. (2016). Pengaruh kepercayaan dan persepsi risiko terhadap minat membeli secara online pada pengunjung website classifieds di Indonesia. Journal of Business Management and Enterpreneurship Education, 1 (1), 181-193.

[9]. Harti. (2017). Pengaruh e-service quality dan diskon terhadap minat beli pada situs online di website zalora.co.id di Surabaya. Jurnal Pendidikan Tata Niaga, 01 (01), 1-4.
[10]. Karnadjaja, C. C., Tulipa, D., \& Lukito, R. S. H. (2017). Pengaruh persepsi risiko, manfaat, dan kemudahan pengunaan terhadap minat belanja online melalui kepercayaan dan sikap pada konsumen Zalora di Surabaya. Kajian Ilmiah Mahasiswa Manajemen, 6 (2), 116-130.

[11]. Kian, T. P., Boon, G. H., Fong, S. T. W., \& Ai, Y. J. (2017). Factors that influence consumer purchase intentions on social media websites. Int. J. Sup. Chain. Mgt, 6 (4), 208-214.

[12]. Jae-Il. K., Lee, H. C., \& Kim, H. J. (2004). Factors affecting online search intention and online purchase intention. Seoul Journal of Business, 10 (2), 27-48.

[13]. Nurrizal, M. (2015). Pengaruh e-service quality dan kepuasan pelanggan terhadap loyalitas dengan moderasi persepsi nilai yang dirasakan pelanggan kereta api di Surabaya. Artiket Ilmiah, 1-22.

[14]. Setyawati, T., Suseno, Y. D., Triastity, R. (2016). Pengaruh keamanan dan kepercayaan terhadap niat beli produk online shop dengan norma subjektif sebagai variabel moderasi. Jurnal Manajemen Sumber Daya Manusia,10 (2), 191-203.

[15]. Suryani, T.(2013). PerilakuKonsumen di Era Internet: Implikasi Pada StrategiPemasaran. Yogyakarta: Grahallmu.

[16]. Venkatesh, V., \& Davis, F. D.(2000). A theoretical extension of the Application Readiness model: Four longitudinal field studies. Management Science,46, 186204.

[17]. Yeh, H. P. (2015). Effects of Ict's innovative applications on brand image and customer's purchase intention.The International Journal Of Organizational Innovation, 7 (4).

[18]. Zeithaml, V. A. A., Parasuraman , A., Malhotra. (2002). Service quality delivery through web sites: a critical review of extant knowledge. Journal of the Academy of Marketing Science, 30 (4). 362-375.

[19]. Zemblyte, J. (2015). The instrument for evaluating eservice quality. Procedia: Social and Behavioral Sciences, 213, 801-806. doi:10.1016/j.sbspro.2015.11.478. 